\title{
Promiscuous Substrate-Binding Explains the Enzymatic Stereo- and Regiocontrolled Synthesis of Enantiopure Hydroxy Ketones and Diols
}

\author{
Marcela Kurina-Sanz, ${ }^{\mathrm{a} *}$ Fabricio R. Bisogno, ${ }^{\mathrm{b}}$ Iván Lavandera, ${ }^{\mathrm{b}}$ Alejandro A. Orden, ${ }^{\mathrm{a}}$ \\ and Vicente Gotor ${ }^{\mathrm{b} *}$ \\ a INTEQUI-CONICET, Área de Química Orgánica, Facultad de Química, Bioquímica y Farmacia, UNSL, Chacabuco y \\ Pedernera, 5700 San Luis, Argentina. \\ Fax number: +54 2652 426711; e-mail: mkurina@unsl.edu.ar. \\ b Departamento de Química Orgánica e Inorgánica, Instituto Universitario de Biotecnología de Asturias, University of \\ Oviedo, 33006 Oviedo, Spain. \\ Fax number: +34 985 103448; e-mail: vgs@ fq.uniovi.es.
}

Received: ((will be filled in by the editorial staff))

Supporting information for this article is available on the WWW under http://dx.doi.org/10.1002/adsc.200\#\#\#\#\#.

\begin{abstract}
Regio- and stereoselective reductions of several diketones to afford enantiopure hydroxy ketones or diols were accomplished using isolated alcohol dehydrogenases (ADHs). Results could be rationalised taking into account different (promiscuous) substrate-binding modes in the active site of the enzyme. Furthermore, interesting natural cyclic diketones were also reduced with high regio- and stereoselectivity.
\end{abstract}

Some of the 1,2- and 1,3-diketones used in this study were reduced employing a low excess of the hydrogen donor (2propanol) due to the quasi-irreversibility of these $\mathrm{ADH}-$ catalysed processes. Thus, using less quantity of cosubstrate, scale-up could be easily achieved.

Keywords: alcohol dehydrogenases; hydroxy ketones; diols; hydrogen transfer; quasi-irreversible reduction

\section{Introduction}

For decades, synthetic organic chemists have devoted their efforts in developing new and versatile protecting-deprotecting strategies in order to selectively modify similar reacting moieties in the same molecule. Hence, considering the loss of the yields and the laborious separation techniques in multistep protocols, a different approach is always desired. Biocatalysis has become a powerful tool for highly stereo- and regioselective transformations due to the intrinsic chirality of enzymes. ${ }^{[1]}$ In particular, biocatalysed regioselective transformations using hydrolases have widely been described in the bibliography, ${ }^{[1,2]}$ while using oxidoreductases have less frequently been performed.

It is well established that enantioenriched anti diols can be readily available through epoxide ring opening starting from the suitable oxirane. ${ }^{[3]}$ On the other hand, syn diols can be obtained via osmium-catalysed oxidation of olefins, among other methods. ${ }^{[4]}$ Enantioselective epoxide hydrolase-catalysed oxirane opening leads to the preparation of anti diols ${ }^{[5]}$ but the intrinsic handicap of the maximum $50 \%$ yield still remains. Aldolases have also been employed to afford syn- or anti-derivatives, although the reversibility of these processes appears as the main drawback. $^{[6]}$
However, the use of alcohol dehydrogenases (ADHs, also called ketoreductases or carbonyl reductases) applied to the synthesis of such important compounds has been scarcely developed. In the last few years, the use of purified or overexpressed ADHs have gained increasing relevance. ${ }^{[7-14]}$ The requirement of expensive nicotinamide cofactors $[\mathrm{NAD}(\mathrm{P}) \mathrm{H}]$ in those processes has slowed down their industrial applicability, although the use of several methodologies to recycle the cofactor have greatly improved the efficacy of these biotransformations. ${ }^{\text {[9- }}$ ${ }_{181}$ In the particular case of the synthesis of enantiopure hydroxy ketones and/or diols starting from the corresponding diketones employing isolated $\mathrm{ADHs}$, there are few examples available in the literature. ${ }^{[19-26]}$ In other cases plants or microorganisms are employed, ${ }^{[27-32]}$ frequently affording a mixture of stereo- and regioisomers due to the action of several enzymes with different and/or opposite selectivities. These derivatives are important building blocks of many natural compounds, ${ }^{[33,34]}$ such as pheromones ${ }^{[35,36]}$ or antitumor agents like discodermolide ${ }^{[37]}$ As a result, they are used as chiral precursors for fine chemicals in the flavour and fragrance- agrochemical-, and pharmaceutical industry. ${ }^{[3 \dot{8}]} \alpha$-Hydroxy ketones (also called acyloins), constitute well-known derivatives for the synthesis of 1,2-amino alcohols through diastereoselective reductive amination. ${ }^{[39]}$ Furthermore, short-chain 
diols can be employed as starting materials for chiral polymers $^{[40]}$ or as backbone for chiral ligands applied to asymmetric transition metal catalysis. ${ }^{\text {[1] }}$

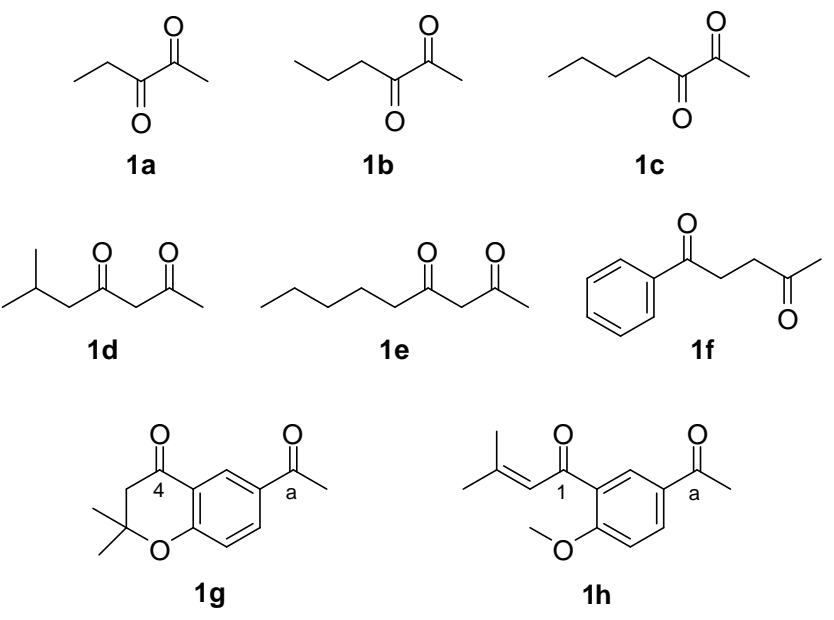

Figure 1. Diketones employed in this study.

Herein we present a stereo- and regioselective ADH-catalysed reduction of several diketones of interest (Figure 1) with excellent ees and des, using internal recycling of cofactor ('substrate-coupled' approach). We will focus on the different substrate recognition modes in order to explain the experimental results obtained, and we will show for the first time the quasi-irreversible reduction concept $^{[42]}$ catalysed by ADHs applied to 1,2- and 1,3-diketones.

\section{Results and Discussion}

As a first step, several diketones (Figure 1) were chosen as suitable substrates to be reduced by commercial ADHs. ${ }^{[43]}$ Thus, 1,2- (1a-c), 1,3- (1d-e), and 1,4-diketones (1f) were firstly used in order to study the acceptance of the tested enzymes (Scheme 1 and Table 1). Lactobacillus brevis $\mathrm{ADH}$ $(\mathrm{LBADH}){ }^{[44]}$ alcohol dehydrogenase from Rhodococcus ruber (ADH-'A'), ${ }^{[4]}$ and $\mathrm{ADH}$ from Thermoanaerobacter sp. $(\mathrm{ADH}-\mathrm{T})^{[46]}$ were selected as biocatalysts to perform the corresponding reductions using an excess of 2-propanol as hydrogen donor, through a 'substrate-coupled' or 'biocatalytic hydrogen transfer' approach. ${ }^{[14]}$ The first enzyme shows a perfect anti-Prelog selectivity, this is, it catalyses the transfer of the hydride to the carbonyl moiety through its si face, while the second and third ADHs display an excellent Prelog profile.<smiles>[R]C(=O)[14CH2]C(C)=O</smiles>

1a-f

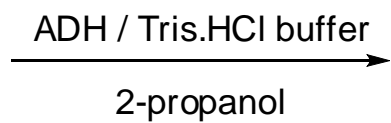

$\mathrm{n}=0,1,2$<smiles>[R]C(=O)[14CH]C([14CH3])O</smiles>

2a-f<smiles>[R]C(O)C(C)=O</smiles>

3a-f<smiles>[R]C(O)[14CH](C)O</smiles>

$4 a-f$

Scheme 1. Regio- and stereoselective reduction of 1,2-, 1,3-, and 1,4-diketones using ADHs and 2-propanol.

Table 1. ADH-catalysed reduction of diketones 1a-f with 2-propanol. ${ }^{[\mathrm{a}]}$

\begin{tabular}{|c|c|c|c|c|c|c|c|c|c|}
\hline Entry & Substrate & $\mathrm{ADH}$ & $2[\%]^{[\mathrm{b}]}$ & e.e. $[\%]^{[\mathrm{c}]}$ & $3[\%]^{[b]}$ & e.e. $[\%]^{[\mathrm{c}]}$ & $4[\%]^{[b]}$ & d.e. $[\%]^{[\mathrm{c}]}$ & e.e. $[\%]^{[\mathrm{c}]}$ \\
\hline 1 & $1 a$ & LBADH & 26 & $>99(R)$ & 3 & $99(R)$ & 69 & $91(2 R, 3 R)$ & $>99$ \\
\hline 2 & $1 \mathbf{a}$ & $\mathrm{ADH}-{ }^{\prime} \mathrm{A}$ ' & 68 & $>99(S)$ & -- & -- & 32 & $62(2 S, 3 R)$ & $>99$ \\
\hline 3 & $1 \mathbf{a}$ & ADH-T & 3 & $99(S)$ & 6 & $66(R)$ & 89 & $74(2 S, 3 R)$ & $>99$ \\
\hline 4 & $1 b$ & LBADH & 92 & $>99(R)$ & -- & -- & 6 & $99(2 R, 3 S)$ & $>99$ \\
\hline 5 & $1 \mathrm{~b}$ & $\mathrm{ADH}-{ }^{\prime} \mathrm{A}$ ' & 49 & $>99(S)$ & 2 & $99(R)$ & 46 & $95(2 S, 3 R)$ & $>99$ \\
\hline 6 & $1 \mathrm{~b}$ & ADH-T & 3 & $99(S)$ & 3 & $99(R)$ & 91 & $96(2 S, 3 R)$ & $>99$ \\
\hline 7 & 1c & LBADH & 42 & $>99(R)$ & -- & -- & 10 & $99(2 R, 3 S)$ & $>99$ \\
\hline 8 & 1c & $\mathrm{ADH}-{ }^{\prime} \mathrm{A}$ ' & 4 & $99(S)$ & -- & -- & 49 & $99(2 S, 3 R)$ & $>99$ \\
\hline 9 & 1c & ADH-T & -- & -- & -- & -- & 62 & $99(2 S, 3 R)$ & $>99$ \\
\hline 10 & 1d & LBADH & $>97$ & $>99(R)$ & -- & -- & -- & -- & -- \\
\hline 11 & 1d & $\mathrm{ADH}-{ }^{\prime} \mathrm{A}$ ' & $>97$ & $>99(S)$ & -- & -- & -- & -- & -- \\
\hline 12 & $1 e$ & LBADH & $>97$ & $>99(R)$ & -- & -- & -- & -- & -- \\
\hline 13 & $1 e$ & $\mathrm{ADH}-{ }^{\circ} \mathrm{A}{ }^{\prime}$ & $>97$ & $>99(S)$ & -- & -- & -- & -- & -- \\
\hline 14 & $\mathbf{1 f}^{[\mathrm{d}]}$ & LBADH & 25 & $>99(R)$ & -- & -- & -- & -- & -- \\
\hline 15 & $\mathbf{1 f}^{[\mathrm{d}]}$ & $\mathrm{ADH}-{ }^{\circ} \mathrm{A}$ ' & 60 & $>99(S)$ & -- & -- & -- & -- & -- \\
\hline 16 & $\mathbf{1 f}^{[\mathrm{d}]}$ & ADH-T & 62 & $>99(S)$ & -- & -- & -- & -- & -- \\
\hline
\end{tabular}

${ }^{[a]}$ Reaction conditions: the corresponding diketone (1a-f, $100 \mathrm{mM}$ ) was added to the $50 \mathrm{mM}$ Tris. $\mathrm{HCl}$ buffer $\mathrm{pH} 7.5 \mathrm{with}$ the corresponding cofactor $(1 \mathrm{mM})$ and 2-propanol $\left(5 \% \mathrm{v} \mathrm{v}^{-1}\right) .{ }^{[\mathrm{b}]}$ Measured by GC. ${ }^{[\mathrm{c}]}$ Calculated by chiral GC. ${ }^{[\mathrm{d}]}$ Less than $5 \%$ of a by-product was formed. 


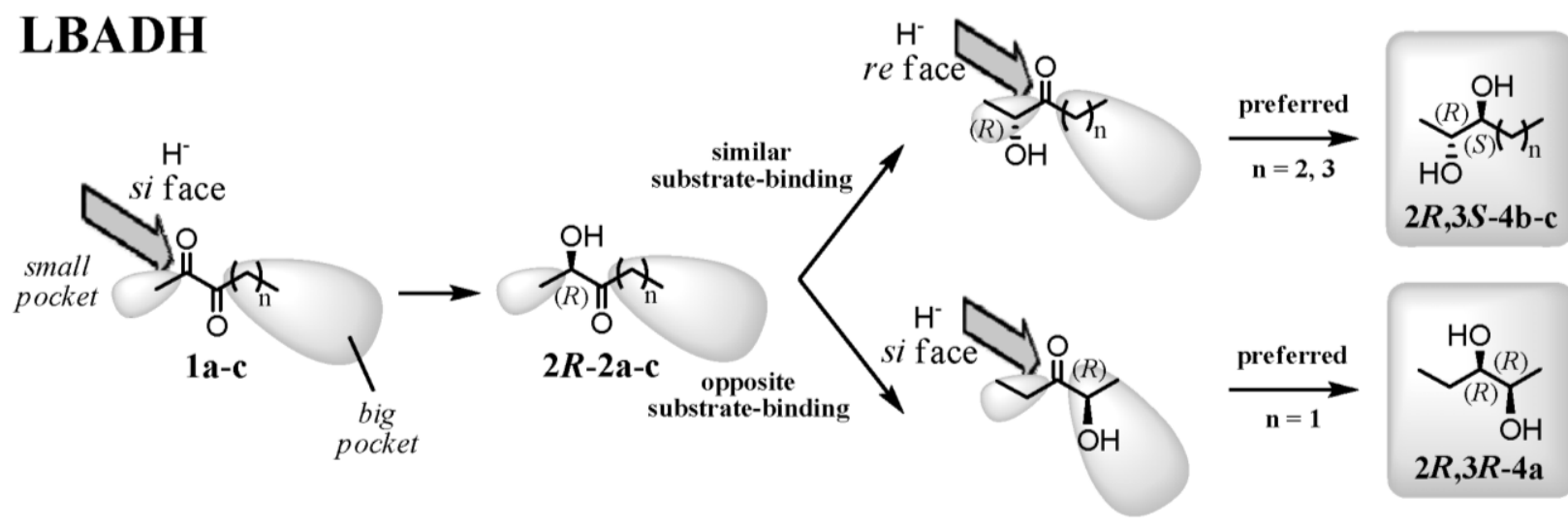

\section{ADH-'A' and ADH-T}

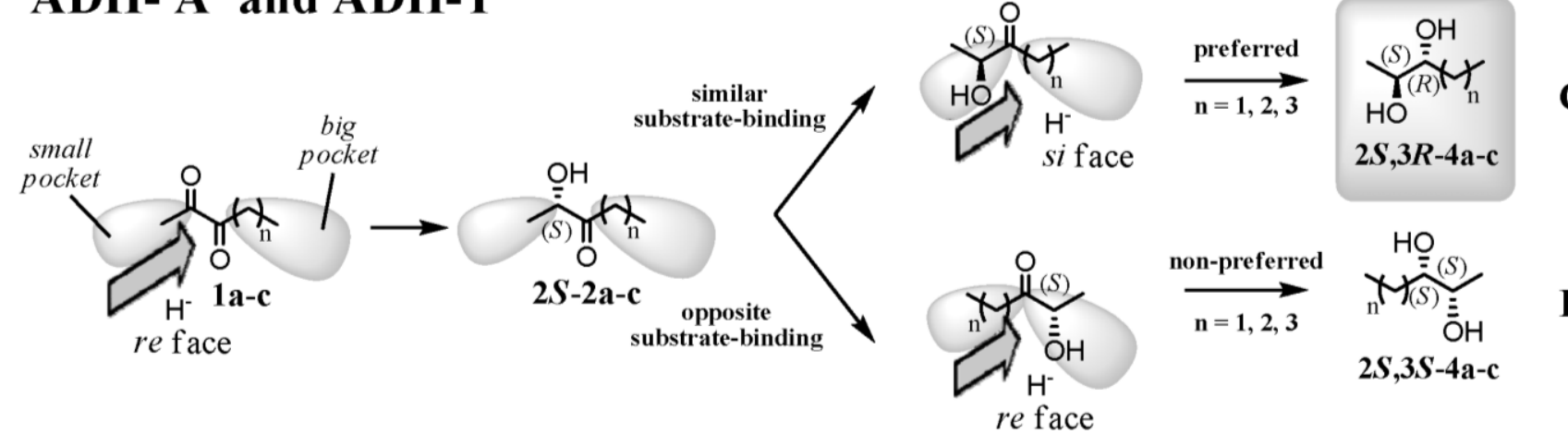

Scheme 2. Promiscuous binding-modes of diketones 1a-c and hydroxy ketones 2a-c in the active site of alcohol dehydrogenases: LBADH (binding-modes A and B); and ADH-'A' and ADH-T (binding-modes C and D).

As can be noted, these ADHs accepted all the tested substrates although showing different behaviour. Thus, with diketone 1a, LBADH mainly afforded enantiopure syn derivative $2 R, 3 R-\mathbf{4 a}$ (entry 1 ), while ADH-'A' mainly provided enantiopure hydroxy ketone $S$-2a (entry 2 ) and ADH-T anti diol $2 S, 3 R$-4a (entry 3). For the other 1,2-diketones $\mathbf{1 b}$ and 1c, LBADH showed a high preference for the regio- and stereoselective reduction of the carbonyl moiety at position 2 , providing $R-\mathbf{2} \mathbf{b}-\mathbf{c}$ and a small quantity of anti diols $2 R, 3 S-\mathbf{4 b}$-c (entries 4 and 7). Meanwhile, Prelog biocatalysts allowed to obtain enantiopure anti diols $2 S, 3 R-\mathbf{4 b}$ and $2 S, 3 R-\mathbf{4 c}$ (entries 6,8 , and 9). On the other hand, the reduction of diketone 1b with ADH-'A' afforded $49 \%$ of the enantiopure hydroxy ketone $S$-2b (entry 5).

Looking at these results, it was obvious that the substrate structure greatly influenced the $\mathrm{ADH}-$ catalysed reductions. For instance, LBADH mainly provided the unexpected syn diol 4a starting from diketone 1a, but when the substrate presented an additional methylene group in the alkyl chain (1b), hydroxy ketone $\mathbf{2 b}$ resulted in the main product and enantiopure anti diol $\mathbf{4 b}$ as minor product. Especially the formation of syn-4a was very remarkable since this enzyme has always been described as a perfect anti-Prelog enzyme. ${ }^{[4]}$ These data can be explained on basis of the promiscuous substrate binding of 1,2diketones at the active site of the enzyme (Scheme 2). Thus, these substrates possess two reactive positions, and therefore different binding-modes can be involved. For 1,2-diketones such as 1a-c, the carbonyl moiety at position 2 will be reduced following the standard fashion, that is, with the methyl group located in the small pocket and the ethylcarbonyl moiety in the big one. The conflict arises when ketone at position 3 is also reduced. Since location of the nicotinamide cofactor is well defined in the active site of $\mathrm{ADHs},{ }^{[47]}$ the hydride attack will take place through the same side, but two possible substrate orientations can exist: $i$ ) a similar one as the previously described, locating the hydroxyethyl group into the small binding-site and the ethyl moiety into the bigger site, thus affording the corresponding anti diols 4a-c (Scheme 2, bindingmodes $\mathrm{A}$ and $\mathrm{C}$ ), or $\mathrm{ii}$ ) the opposite substrate-binding providing the syn derivatives (Scheme 2, bindingmodes B and D). Depending on the pockets size of the biocatalyst, one mode will be favoured at the expense of the second one, and therefore different regio- and stereoisomer ratios will be obtained.

From the obtained results, LBADH favoured the opposite disposition of hydroxy ketone 2a with regards to diketone 1a (Scheme 2, mode A), while for alcohols 2b-c a similar binding was preferred (Scheme 2, mode B). For 2b-c, since in the reverse binding-mode a propyl or a butyl moiety, respectively, should be located in the small pocket, this biocatalyst was not able to afford the corresponding syn diols. The hydroxyethyl group already seems to crowd the 
small pocket of this $\mathrm{ADH}$ due to the low conversions obtained (less than 10\%) for $\mathbf{4 b - c}$ (Table 1, entries 4 and 7). On the other hand, $\mathrm{ADH}-{ }^{\prime} \mathrm{A}$ ' and $\mathrm{ADH}-\mathrm{T}$ always preferred a similar disposition for 1a-c and 2a-c placing the larger acyl chain into the bigger binding-site (Scheme 2, mode $\mathrm{C}$ ), thus mainly affording the corresponding anti diols 4a-c. As larger the difference between the acyl chain and the hydroxyethyl moiety was, better the des favouring the anti derivatives were (Table 1, compare entries 2-3 with 5-6 and 8-9).

A clearer scenario appeared when 1,3- or 1,4diketones (1d-f) were subjected to the hydrogen transfer conditions (Table 1, entries 10 to 16). ADHs showed perfect regio- and stereoselectivity achieving the reduction of the carbonyl moiety at position 2 to afford enantiopure $R-\mathbf{2 d - f}$ (in the case of LBADH) or $S$-2d-f (in the case of ADH-'A' and ADH-T) alcohols. Diketone 1f was less well accepted, obtaining moderate (with LBADH) or good conversions (with both Prelog enzymes). In this case another by-product (less than 5\%) was formed.

The selective modification of natural compounds in order to obtain novel derivatives with enhanced biological activities is a difficult task which organic chemists must often face. ${ }^{[48,49]}$ In our particular case, the natural product 6-acetyl-2,2-dimethyl-2,3dihydro-4H-chromen-4-one (1g) and the derivative 1(5-acetyl-2-methoxyphenyl)-3-methylbut-2-en-1-one (1h) were also chosen as substrates to study the regioand stereoselectivity in the bioreduction processes catalysed by isolated ADHs (Table 2). The former was isolated from Ophryosporus axilliflorus (Griseb.) Hieron (Asteraceae). These and other related compounds showed anti-inflammatory activity. ${ }^{[50]}$ Previous reductions of diketone $1 \mathrm{~g}$ using plants were reported. ${ }^{[27,51]}$ It remained clear that LBADH was not a suitable enzyme to perform these bioreductions due to low conversions (entries 1 and 4). This is in concordance with the small active site of this biocatalyst. On the contrary, $\mathrm{ADH}-{ }^{\prime} \mathrm{A}$ ' and $\mathrm{ADH}-\mathrm{T}$ were able to regioselectively reduce both substrates on the acetyl moiety $\left(\mathrm{C}_{\mathrm{a}}\right)$ affording highly pure $(S)$-2g and $\mathbf{2 h}$ alcohols (entries 2, 3, 5 and 6).

Table 2. ADH-catalysed reduction of natural compounds 1g-h with 2-propanol. ${ }^{[\mathrm{a}]}$

\begin{tabular}{lllll}
\hline Entry & Substrate & ADH & $\mathbf{2}[\%]^{[\mathrm{b}]}$ & e.e. $[\%]^{[\mathrm{c}]}$ \\
\hline 1 & $\mathbf{1 g}$ & LBADH & 9 & $>99(R)$ \\
2 & $\mathbf{1 g}$ & ADH-'A' & 90 & $94(S)$ \\
3 & $\mathbf{1 g}$ & ADH-T & 86 & $90(S)$ \\
4 & $\mathbf{1 h}$ & LBADH & 3 & n. d. \\
5 & $\mathbf{1 h}$ & ADH-'A' & 95 & $>99(S)$ \\
6 & $\mathbf{1 h}$ & ADH-T & 45 & $>99(S)$ \\
\hline
\end{tabular}

[a] Reaction conditions: the corresponding diketone (1g-h, $50 \mathrm{mM}$ ) was added to the $50 \mathrm{mM}$ Tris. $\mathrm{HCl}$ buffer $\mathrm{pH} 7.5$ with the corresponding cofactor $(1 \mathrm{mM})$ and 2-propanol $\left(5 \% \mathrm{~V} \mathrm{v}^{-1}\right){ }^{[\mathrm{b}]}$ Measured by GC. ${ }^{[\mathrm{c}]}$ Calculated by chiral HPLC. n. d. not determined.
Until this point, we were pleased to find out that different kind of diketones could regio- and stereoselectively be reduced by the tested ADHs. Having in mind the scale-up of these processes, we tried to perform the bioreductions at lower cosubstrate concentration, using less harmful conditions for the biocatalyst and maximising the atom efficiency ${ }^{[52]}$ of the process. We envisaged the possible irreversibility in the reduction of 1,2- and 1,3-diketones since it has previously been described that 1-chloro-2-propanol ${ }^{[42]}$ cannot be oxidised by ADHs due to an intramolecular $\mathrm{H}$-bond interaction between the hydroxyl group and the halogen atom. ${ }^{[53]}$ Thus, 1,2- or 1,3-diketones could quasi-irreversibly be reduced since it is well known that the corresponding hydroxy ketones show a strong intramolecular interaction via $\mathrm{H}$-bonding network (Figure 2). ${ }^{[54]}$<smiles></smiles><smiles>[R]C1=CO[CH]OC([R])C1</smiles>

\section{1,2-hydroxy ketone}

1,3-hydroxy ketone

Figure 2. Intramolecular $\mathrm{H}$-bond interactions in 1,2- and 1,3-hydroxy ketones.

In order to demonstrate this fact, ${ }^{[55]}$ we repeated the LBADH catalysed reduction of diketones $\mathbf{1 b}, \mathbf{1 d}$, and 1e employing different concentrations of 2propanol (from 2 equiv. to 10 equiv.), and results were compared with that obtained in the case of a non-activated ketone such as 2-octanone (1i). As can be noticed (Table 3 ), diketones were reduced into the corresponding hydroxy ketones $(c>90 \%)$ even at low 2-propanol concentration (entries 1, 4 and 7). On the contrary, for ketone 1i (entry 10) conversion was $67 \%$ due to the similar equilibrium constants between the 2-octanone/2-octanol and acetone/2-propanol pairs. ${ }^{[56]}$

Table 3. LBADH-catalysed reduction of 1,2- (1b), 1,3diketones (1d-e) and 2-octanone (1i), using different concentrations of 2-propanol. ${ }^{[\mathrm{a}]}$

\begin{tabular}{llll}
\hline Entry & Substrate & [2-propanol] $[\mathrm{M}]$ & $\mathbf{2}[\%]^{[\mathrm{b}]}$ \\
\hline 1 & $\mathbf{1 b}$ & 0.2 & 94 \\
2 & $\mathbf{1 b}$ & 0.5 & 95 \\
3 & $\mathbf{1 b}$ & 1 & 97 \\
4 & $\mathbf{1 d}$ & 0.2 & 92 \\
5 & $\mathbf{1 d}$ & 0.5 & 91 \\
6 & $\mathbf{1 d}$ & 1 & 94 \\
7 & $\mathbf{1 e}$ & 0.2 & 95 \\
8 & $\mathbf{1 e}$ & 0.5 & 94 \\
9 & $\mathbf{1 e}$ & 1 & 92 \\
10 & $\mathbf{1 i}$ & 0.2 & 67 \\
\hline
\end{tabular}

[a] Reaction conditions: the corresponding diketone (100 $\mathrm{mM}$ ) was added to the $50 \mathrm{mM}$ Tris. $\mathrm{HCl}$ buffer $\mathrm{pH} 7.5$ with the corresponding cofactor $(1 \mathrm{mM})$ and 2-propanol (200 $\mathrm{mM}-1 \mathrm{M}) .{ }^{[\mathrm{b}]}$ Measured by GC. 
Since a small amount of 2-propanol (2 equiv.) can be employed to quantitatively reduce this type of substrates, enantiopure $(R)$-alcohols $\mathbf{2 b}, \mathbf{2 d}$, and $2 \mathbf{2 e}$ were prepared on a higher scale starting from $25 \mathrm{mg}$ of the corresponding diketones with isolated yields higher than $80 \%$.

\section{Conclusions}

The bioreduction of diketones has not been extensively studied, ${ }^{[19-26]}$ and in several cases microorganisms or plants ${ }^{[27-32]}$ were used for this purpose. Thus, the obtained results in terms of regioand stereoselectivity usually remained unclear. Herein we have shown the bioreduction of several diketones of interest catalysed by isolated alcohol dehydrogenases. With the advantage of using a single enzyme, we have proposed that in reductions of 1,2diketones, these substrates can be suited within the active site of the enzyme in two different orientations depending on the size of the enzyme pockets. Hence, just by choosing the proper catalyst, syn or anti products could be obtained. For instance, due to its small binding-site, LBADH presents a promiscuous binding for the diketone 1a and the hydroxy ketone intermediate to afford the corresponding syn-diol. On the other hand, $\mathrm{ADH}-{ }^{-} \mathrm{A}$ ' and $\mathrm{ADH}-\mathrm{T}$ favour a similar recognition mode for both species, thus mainly providing the anti-derivatives. This is an elegant example of enzyme-based stereocontrol. ${ }^{[57]} \mathrm{In}$ the case of the other diketones studied, perfect regioand stereoselectivity was achieved obtaining the corresponding enantiopure hydroxy ketones.

In addition, it has been demonstrated that 1,2- or 1,3-diketones can be reduced via $\mathrm{ADH}$-catalysed hydrogen transfer using quasi-irreversible conditions, ${ }^{[42]}$ this is, employing a low excess of the required co-substrate (2-propanol). This is due to the difficulty of the enzyme to oxidise backwards the formed hydroxy ketone due to an intramolecular $\mathrm{H}$ bond interaction between the hydroxyl and the remaining carbonyl moiety. Since a lower amount of the hydrogen donor (usually used in a huge excess) is needed, the scale-up of the ADH-catalysed reductions of such compounds is feasible.

\section{Experimental Section}

General. Alcohol dehydrogenases and ketones 1a-1f, 1i were purchased from commercial sources. Ketone $\mathbf{1 g}$ was isolated from aerial parts of Ophryosporus axilliflorus (Griseb.) Hieron according to Favier et al. ${ }^{\text {50] }}$ The same procedure also afforded the diketone 1-(5-acetyl-2hydroxyphenyl)-3-methylbut-2-en-1-one which was methylated by classical methods $\left(\mathrm{Me}_{2} \mathrm{SO}_{4}, \mathrm{~K}_{2} \mathrm{CO}_{3}\right.$, under acetone reflux, 2 h) to obtain $\mathbf{1 h}$. Racemic alcohols $\mathbf{2 a - h}$, 3a-c and 4a-c were purchased or synthesised by conventional reduction from the corresponding ketones $\left(\mathrm{NaBH}_{4}, \mathrm{MeOH}, 0^{\circ} \mathrm{C}\right.$ or room temperature). All other reagents and solvents were of the highest quality available. 1 unit (U) of ADH reduces $1.0 \mu \mathrm{M}$ of acetophenone to 1 phenylethanol per minute at $\mathrm{pH} 7.5$ and $30{ }^{\circ} \mathrm{C}$ in the presence of $\mathrm{NAD}(\mathrm{P}) \mathrm{H}$. Flash chromatography was performed using silica gel 60 (230-400 mesh).
General protocol for the biocatalytic reduction of diketones employing ADHs and 2-propanol. In a $1.5 \mathrm{~mL}$ Eppendorf vial, $3 \mathrm{U}$ of ADH (Lactobacillus brevis $\mathrm{ADH}$ Rhodococcus ruber ADH-'A', or Thermoanaerobacter sp. $\mathrm{ADH}$ ) in Tris. $\mathrm{HCl}$ buffer $[50 \mathrm{mM}, \mathrm{pH} 7.5,1 \mathrm{mM}$ $\mathrm{NAD}(\mathrm{P}) \mathrm{H}, 1 \mathrm{mM} \mathrm{MgCl}{ }_{2}$ for LB-ADH] were mixed with 2 propanol $\left(32 \mu \mathrm{L}, 5 \% \mathrm{v} \mathrm{v}^{-1}\right)$ and the corresponding diketone (1a-1f, and 1i, $100 \mathrm{mM} ; \mathbf{1 g}-1 \mathrm{~h}, 50 \mathrm{mM})$. Reactions were shaken at $30{ }^{\circ} \mathrm{C}$ and $120 \mathrm{rpm}$ for $24 \mathrm{~h}$ and stopped by extraction with ethyl acetate $(2 \times 0.5 \mathrm{~mL})$. The organic layer was separated by centrifugation ( $2 \mathrm{~min}, 13000 \mathrm{rpm}$ ) and dried $\left(\mathrm{Na}_{2} \mathrm{SO}_{4}\right)$. Conversions and enantiomeric excesses of the corresponding alcohols were determined by GC or HPLC analysis on an achiral or a chiral stationary phase, respectively (see Supporting Information).

General protocol for the biocatalytic reduction of diketones employing LBADH with different concentrations of 2-propanol. In a $1.5 \mathrm{~mL}$ Eppendorf vial, $3 \mathrm{U}$ of LBADH in Tris. $\mathrm{HCl}$ buffer $(50 \mathrm{mM}, \mathrm{pH} 7.5,1 \mathrm{mM}$ NADPH, $1 \mathrm{mM} \mathrm{MgCl}$ ) were mixed with 2-propanol (200 mM-1 M) and the corresponding diketone $(\mathbf{1 b}, \mathbf{1 d}, \mathbf{1 e}$ or $\mathbf{1 i}$, $100 \mathrm{mM})$. Reactions were shaken at $30^{\circ} \mathrm{C}$ and $120 \mathrm{rpm}$ for $24 \mathrm{~h}$ and stopped by extraction with ethyl acetate $(2 \times 0.5$ $\mathrm{mL})$. The organic layer was separated by centrifugation (2 min, $13000 \mathrm{rpm})$ and dried $\left(\mathrm{Na}_{2} \mathrm{SO}_{4}\right)$. Conversions were determined by GC analysis on an achiral stationary phase (see Supporting Information).

Representative example for biocatalytic reduction of a diketone: preparation of $(\boldsymbol{R})-2 d$. In a $5 \mathrm{~mL}$ screw-capped tube $5 \mathrm{U}$ of LBADH in Tris. $\mathrm{HCl}$ buffer $(1.8 \mathrm{~mL}, 50 \mathrm{mM}$, $\mathrm{pH} 7.5,1 \mathrm{mM}$ NADPH, $1 \mathrm{mM} \mathrm{MgCl}$ ) were mixed with 2propanol $(27.5 \mu \mathrm{L}, 0.36 \mathrm{mmol})$ and $1 \mathrm{~d}(28 \mu \mathrm{L}, 0.18 \mathrm{mmol})$. Reactions were shaken at $30^{\circ} \mathrm{C}$ and $120 \mathrm{rpm}$ for $24 \mathrm{~h}$ and stopped by extraction with ethyl acetate $(3 \times 1 \mathrm{~mL})$. The organic layer was separated by centrifugation $(2 \mathrm{~min}$ $13000 \mathrm{rpm})$ and dried $\left(\mathrm{Na}_{2} \mathrm{SO}_{4}\right)$. Alcohol $2 d$ was purified by flash chromatography (petroleum ether:EtOAc 4:1) obtaining thus $21.5 \mathrm{mg}(83 \%)$ of enantiopure $(R)-2 d$ : colourless oil; $[\alpha]_{\mathrm{D}}{ }^{20}-13.7$ (c 1.5 in $\mathrm{CHCl}_{3}$ ); IR (neat) 3420 , 2960, 2874, 1707, 1467, 1370, and $1125 \mathrm{~cm}^{-1}$; ${ }^{1} \mathrm{H}-\mathrm{NMR}$ $\left(\mathrm{CDCl}_{3}, 300 \mathrm{MHz}\right) \delta 0.92\left(d, 6 \mathrm{H}, \mathrm{H}_{7},{ }^{3} \mathrm{~J}_{\mathrm{HH}} 6.6 \mathrm{~Hz}\right), 1.18(d$, $\left.3 \mathrm{H}, \mathrm{H}_{1},{ }^{3} \mathrm{~J}_{\mathrm{HH}} 6.4 \mathrm{~Hz}\right), 2.07-2.20\left(m, 1 \mathrm{H}, \mathrm{H}_{6}\right), 2.30(d, 2 \mathrm{H}$, $\left.\mathrm{H}_{5},{ }^{3} \mathrm{~J}_{\mathrm{HH}} 6.8 \mathrm{~Hz}\right), 2.48\left(d d, 1 \mathrm{H}, \mathrm{H}_{3},\left.\right|^{2} \mathrm{~J}_{\mathrm{HH}}, 17.8{ }^{3} \mathrm{~J}_{\mathrm{HH}} 8.8 \mathrm{~Hz}\right)$, $2.59\left(d d, 1 \mathrm{H}, \mathrm{H}_{3},\left.\right|^{2} \mathrm{~J}_{\mathrm{HH}} \mid 17.8{ }^{3} \mathrm{~J}_{\mathrm{HH}} 3.1 \mathrm{~Hz}\right)$, and $4.22(\mathrm{~m}, 1 \mathrm{H}$, $\left.\mathrm{H}_{2}\right)$; ${ }^{3} \mathrm{C}-\mathrm{NMR}\left(\mathrm{CDCl}_{3}, 75.5 \mathrm{MHz}\right) \delta 22.2\left(\mathrm{C}_{1}\right), 22.4(2 \mathrm{C}$, $\left.\mathrm{C}_{7}\right), 24.5\left(\mathrm{C}_{6}\right), 50.8\left(\mathrm{C}_{3}\right.$ or $\left.\mathrm{C}_{5}\right), 52.4\left(\mathrm{C}_{3}\right.$ or $\left.\mathrm{C}_{5}\right), 63.7\left(\mathrm{C}_{2}\right)$, and $212.2\left(\mathrm{C}_{4}\right) ; \mathrm{MS}\left(\mathrm{APCI}^{+}\right): m / z(\%)=144(3)[\mathrm{M}]^{+}, 129$ (6) $\left[\mathrm{M}-\mathrm{CH}_{3}\right]^{+}, 126(8)\left[\mathrm{M}-\mathrm{H}_{2} \mathrm{O}\right]^{+}, 111(22), 87(42), 69$ (61), 57 (80), and 43 (100).

\section{Acknowledgements}

M.K.-S. is member of the Research Career of CONICET. A.A.O. is a postdoctoral CONICET fellow. F.R.B. is supported by the Programme Alßan, the European Union Program of High Level Scholarships for Latin America (scholarship No. E07D402519AR). I.L. thanks Principado de Asturias for personal funding (Clarín Program). Financial support from the Spanish Ministerio de Ciencia e Innovación (MICINN, Project CTQ200761126) and the Spanish Ministerio de Asuntos Exteriores y de Cooperación (Programa de Cooperación Interuniversitaria, PCI Iberoamérica MAEC-AECID, Project A/8856/07) is gratefully acknowledged.

\section{References}

[1] Asymmetric Organic Synthesis with Enzymes, (Eds.: V. Gotor, I. Alfonso, E. García-Urdiales), Wiley-VCH, Weinheim, 2008. 
[2] U. T. Bornscheuer, R. J. Kazlauskas, Hydrolases in Organic Synthesis, 2nd ed., Weinheim: Wiley-VCH, 2005.

[3] M. Tokunaga, J. F. Larrow, F. Kakiuchi, E. N. Jacobsen, Science 1997, 277, 936-938.

[4] C. Bolm, J. P. Hildebrand, K. Muniz in Catalytic Asymmetric Synthesis, (Ed.: I. Ojima), 2nd ed., WileyVCH, New York, 2000, pp. 399-428.

[5] R. Chênevert, P. Morin, N. Pelchat in Asymmetric Organic Synthesis with Enzymes, (Eds.: V. Gotor, I. Alfonso, E. García-Urdiales), Wiley-VCH, Weinheim, 2008, pp. 133-169.

[6] W.-D. Fessner in Asymmetric Organic Synthesis with Enzymes, (Eds.: V. Gotor, I. Alfonso, E. GarcíaUrdiales), Wiley-VCH, Weinheim, 2008, pp. 275-318.

[7] H. Li, D. Zhu, L. Hua, E. R. Biehl, Adv. Synth. Catal. 2009, 351, 583-588.

[8] M. J. Sorgedrager, F. van Rantwijk, G. W. Huisman, R. A. Sheldon, Adv. Synth. Catal. 2008, 350, 2322-2328.

[9] S. Buchholz, H. Gröger in Biocatalysis in the Pharmaceutical and Biotechnology Industry, (Ed.: R. N. Patel), CRC Press, Boca Raton, 2007, pp. 757-790.

[10] S. M. A. de Wildeman, T. Sonke, H. E. Schoemaker, O. May, Acc. Chem. Res. 2007, 40, 1260-1266.

[11] J. C. Moore, D. J. Pollard, B. Kosjek, P. N. Devine, Acc. Chem. Res. 2007, 40, 1412-1419.

[12] K. Goldberg, K. Schroer, S. Lütz, A. Liese, Appl. Microbiol. Biotechnol. 2007, 76, 237-248.

[13] W. Kroutil, H. Mang, K. Edegger, K. Faber, $A d v$. Synth. Catal. 2004, 346, 125-142.

[14] W. Kroutil, H. Mang, K. Edegger, K. Faber, Curr. Opin. Chem. Biol. 2004, 8, 120-126.

[15] I. Lavandera, A. Kern, M. Schaffenberger, J. Gross, A. Glieder, S. de Wildeman, W. Kroutil, ChemSusChem 2008, 1, 431-436.

[16] H. Gröger, C. Rollmann, F. Chamouleau, I. Sebastien, O. May, W. Wienand, K. Drauz, Adv. Synth. Catal. 2007, 349, 709-712.

[17] M. M. Musa, K. I. Ziegelmann-Fjeld, C. Vieille, J. G. Zeikus, R. S. Phillips, Angew. Chem. 2007, 119, 31513154; Angew. Chem. Int. Ed. 2007, 46, 3091-3094.

[18] W. A. van der Donk, H. Zhao, Curr. Opin. Biotechnol. 2003, 14, 421-426.

[19] S. Lüdeke, M. Richter, M. Müller, Adv. Synth. Catal. 2009, 351, 253-259.

[20] M. Katzberg, K. Wechler, M. Müller, P. Dünkelmann, J. Stohrer, W. Hummel, M. Bertau, Org. Biomol. Chem. 2009, 7, 304-314.

[21] B. T. Grau, P. N. Devine, L. N. DiMichele, B. Kosjek, Org. Lett. 2007, 9, 4951-4954.

[22] D. Kalaitzakis, J. D. Rozzell, I. Smonou, S. Kambourakis, Adv. Synth. Catal. 2006, 348, 2309-2313.
[23] J. Haberland, A. Kriegesmann, E. Wolfram, W. Hummel, A. Liese, Appl. Microbiol. Biotechnol. 2002, 58, 595-599.

[24] A. Matsuyama, H. Yamamoto, N. Kawada, Y. Kobayashi, J. Mol. Catal. B: Enzym. 2001, 11, 513-521.

[25] Y. Kawai, K. Hida, M. Tsujimoto, S. Kondo, K. Kitano, K. Nakamura, A. Ohno, Bull. Chem. Soc. Jpn. 1999, 72, 99-102.

[26] O. Bortolini, G. Fantin, M. Fogagnolo, P. P. Giovannini, A. Guerrini, A. Medici, J. Org. Chem. 1997, 62, 1854-1856.

[27] A. A. Orden, F. R. Bisogno, O. S. Giordano, M. Kurina-Sanz, J. Mol. Catal. B: Enzym. 2008, 51, 49-55.

[28] K. Edegger, W. Stampfer, B. Seisser, K. Faber, S. F. Mayer, R. Oerhrlein, A. Hafner, W. Kroutil, Eur. J. Org. Chem. 2006, 8, 1904-1909.

[29] P. Boutoute, G. Mousset, H. Veschambre, New J. Chem. 1998, 22, 247-251.

[30] H. Ikeda, E. Sato, T. Sugai, H. Ohta, Tetrahedron 1996, 52, 8113-8122.

[31] P. Besse, J. Bolte, A. Fauve, H. Veschambre, Bioorg. Chem. 1993, 21, 342-353.

[32] J.-X. Gu, Z.-Y. Li, G.-Q. Lin, Tetrahedron 1993, 49, 5805-5816.

[33] M. Kalesse, M. Christmann, Synthesis 2002, 9811003.

[34] S. D. Rychnovsky, Chem. Rev. 1995, 95, 2021-2040.

[35] D. A. Higgins, M. E. Pomianek, C. M. Kraml, R. K. Taylor, M. F. Semmelhack, B. L. Bassler, Nature 2007, 450, 883-886.

[36] W. S. Leal, X. Shi, K. Nakamuta, M. Ono, J. Meinwald, Proc. Natl. Acad. Sci. USA 1995, 92, 10381042.

[37] M. Kalesse, ChemBioChem 2000, 1, 171-175.

[38] M. Breuer, K. Ditrich, T. Habicher, B. Hauer, M. Kesseler, R. Stürmer, T. Zelinski, Angew. Chem. 2004 116, 806-843; Angew. Chem. Int. Ed. 2004, 43, 788824.

[39] A. J. Smallridge, M. A. Trewhalla, A. Maurice, A. K. Wilkinson, WO Patent 2003018531A1 20030306, Chem. Abstr. 2003, 138, 205242.

[40] G. N. Bennet, K. Y. San, Appl. Microbiol. Biotechnol. 2001, 55, 1-9.

[41] M. J. Burk, M. F. Gross, J. P. Martinez, J. Am. Chem. Soc. 1995, 117, 9375-9376.

[42] I. Lavandera, A. Kern, V. Resch, B. Ferreira-Silva, A. Glieder, W. M. F. Fabian, S. de Wildeman, W. Kroutil, Org. Lett. 2008, 10, 2155-2158.

[43] ADHs have been purchased from Codexis or Jülich, a Codexis company. 
[44] M. Wolberg, W. Hummel, C. Wandrey, M. Müller, Angew. Chem. 2000, 112, 4476-4478; Angew. Chem. Int. Ed., 2000, 39, 4306-4308.

[45] W. Stampfer, B. Kosjek, C. Moitzi, W. Kroutil, K. Faber, Angew. Chem. 2002, 114, 1056-1059; Angew. Chem. Int. Ed. 2002, 41, 1014-1017.

[46] Z. Findrik, D. Vasić-Racki, S. Lütz, T. Daussmann, C. Wandrey, Biotechnol. Lett. 2005, 27, 1087-1095.

[47] See, for instance: N. H. Schlieben, K. Niefind, J. Müller, B. Riebel, W. Hummel, D. Schomburg, J. Mol. Biol. 2005, 349, 801-813.

[48] S. Riva, J. Mol. Catal. B: Enzym. 2002, 19-20, 43-54.

[49] M. Ferrero, V. Gotor, in Enzymes in Action. Green Solutions for Chemical Problems, (Eds.: B. Zwanenburg, M. Mikolajczyk, P. Kielbasinski), Kluwer Academic Plublishers, Dordrecht, The Netherlands, 2000, pp. 347-363.

[50] L. Favier, C. Tonn, E. Guerreiro, A. Rotelli, L. Pelzer, Planta Med. 1998, 64, 657-659.

[51] A. A. Orden, F. R. Bisogno, D. Cifuente, O. S. Giordano, M. Kurina-Sanz, J. Mol. Catal. B: Enzym. 2006, 42, 71-77.
[52] B. M. Trost, Science 1991, 254, 1471-1477.

[53] T. Goldstein, M. S. Snow, B. J. Howard, J. Mol. Spectrosc. 2006, 236, 1-10.

[54] In fact, in a very recent published patent $\beta$-keto esters were used as oxidants: C. Peschko, J. Stohrer, Wacker Chemie AG, DE Patent 102006009743, A1 20070906, Chem. Abstr. 2007, 147, 321414.

[55] Further experiments were carried out in order to prove that ADHs clearly favoured the reduction of diketones over the oxidation of hydroxy ketones. Thus, the corresponding reverse ADH-catalysed oxidations with hydroxy ketones $\mathbf{2 b}, \mathbf{2 d}$, and $\mathbf{2 e}$ were made using an excess of acetone, obtaining that $\mathbf{2 b}$ was not oxidised backwards while $\mathbf{2 d}$ and $\mathbf{2 e}$ were slightly oxidised (around $15 \%$ conversion).

[56] M. F. Eckstein, M. Peters, J. Lembrecht, A. C. Spiess, L. Greiner, Adv. Synth. Catal. 2006, 348, 1591-1596.

[57] M. Hall, C. Stueckler, H. Ehammer, E. Pointner, G. Oberdorfer, K. Gruber, B. Hauer, R. Stuermer, W. Kroutil, P. Macheroux, K. Faber, Adv. Synth. Catal. 2008, 350, 411-418. 


\section{FULL PAPER}

Promiscuous Substrate-Binding Explains the Enzymatic Stereo- and Regiocontrolled Synthesis of Enantiopure Hydroxy Ketones and Diols

Adv. Synth. Catal. 2009, 351, Page - Page

Marcela Kurina-Sanz, * Fabricio R. Bisogno, Iván

Lavandera, Alejandro A. Orden, and Vicente

Gotor*

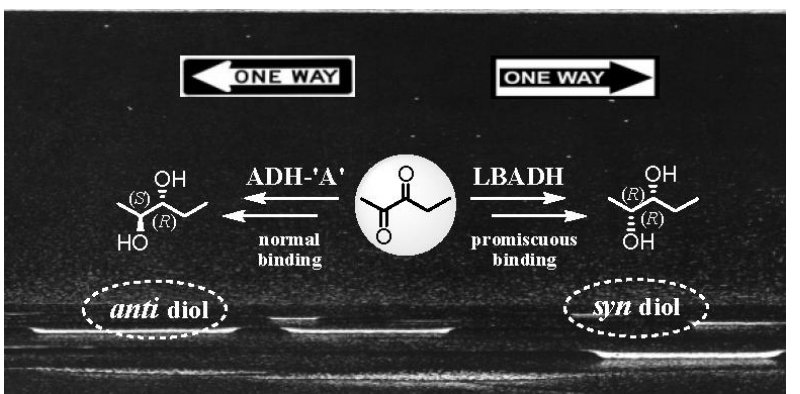

